\title{
Tempos máximos de fonação de vogais em mulheres adultas com nódulos vocais***
}

\author{
Maximum phonation time of vowels in adult women with vocal \\ nodules
}

\author{
Laura Oliveira Kurtz* \\ Carla Aparecida Cielo*
}

\author{
*Fonoaudióloga. Mestranda em \\ Distúrbios da Comunicação Humana \\ pela Universidade Federal de Santa \\ Maria (UFSM). Fonoaudióloga da \\ Escola Municipal de Ensino Especial \\ Tanara Girardon Julien. Endereço para \\ correspondência: R. Vale Machado, \\ 1646 - Apto 401 - Santa Maria - RS - \\ CEP 97010-530 \\ (lauraolik@yahoo.com.br). \\ *Fonoaudióloga. Doutora em \\ Linguística Aplicada pela Pontifícia \\ Universidade Católica do Rio Grande \\ do Sul. Professor Adjunto do \\ Departamento de Fonoaudiologia e do \\ Programa de Pós-Graduação em \\ Distúrbios da Comunicação Humana da \\ UFSM. \\ ***Trabalho Realizado no Laboratório \\ de Voz da UFSM.
}

\section{Artigo Original de Pesquisa}

Artigo Submetido a Avaliação por Pares

Conflito de Interesse: não

Recebido em 05.04.2010.

Revisado em 06.09.2010; 22.11.2010.

Aceito para Publicação em 30.11.2010.

\begin{abstract}
Background: maximum phonation times (MPT) of vowels in adult women with vocal nodules. Aim: to verify and to correlate the values of MPT of vowels in young and middle-aged adult women with vocal nodules. Method: database records from a speech therapy school-clinic were used, making up a total of 38 subjects. Inclusion criteria: female adults, aged between 20 and 53 years, with otorhinolaryngology diagnosis of vocal nodules. Exclusion criteria: to present a laryngeal pathology other than vocal nodules; hearing loss ; oral breathing; history of neurological, psychiatric, endocrine or gastric disorders; flu or allergy history; drinking and/or smoking habits; previous speech therapy and/or otorhinolaryngology treatments. Anamnesis data, the otorhinolaryngology diagnosis, and the MPT measurements of vowels /a, i, u/ were verified for each subject. MPT evaluation consisted of the duration measurement of three emissions of the vowels, using habitual tone and intensity, until the end of exhalation, with the patient in a standing position, considering the highest value of each vowel. The results were statistically analyzed with a significance level of 5\%. Results: representative age range; less representative MPT and mean, below normality and with a strong positive and meaningful correlation; moderate, positive and significant correlation between MPTs and their means. Conclusion: for the group of adult women with vocal nodules, the MPT values were reduced and positively correlated; the MPT of vowel /a/ presented a lower value when compared to the other investigated vowels.
\end{abstract}

Key Words: Voice; Phonation; Vocal Folds; Voice Disorders.

\section{Resumo}

Tema: tempos máximos de fonação (TMF) de vogais em mulheres adultas com presença de nódulos vocais. Objetivo: verificar e correlacionar os valores de TMF de vogais em mulheres adultas jovens e de meia-idade com presença de nódulos vocais. Método: utilizaram-se os registros do Banco de dados de uma clínica-escola de Fonoaudiologia, totalizando um grupo de 38 sujeitos. Critérios de inclusão: adultos do sexo feminino com idades entre 20 e 53 anos e diagnóstico otorrinolaringológico de nódulos vocais. Critérios de exclusão: apresentar outra patologia laríngea além dos nódulos vocais; comprometimento auditivo; respiração oral; histórico de doenças neurológicas, psiquiátricas, endocrinológicas ou gástricas; gripe ou quadros de alergias; hábitos de etilismo e/ou tabagismo; tratamento fonoaudiológico e/ou otorrinolaringológico prévios. Foram coletados os dados de anamnese, o diagnóstico otorrinolaringológico, e as medidas de TMF das vogais /a, i, $\mathrm{u} /$ de cada sujeito da amostra. A avaliação dos TMF se deu pela medida da duração de três emissões de cada vogal em estudo, em tom e intensidade habituais, até o final da expiração, com o paciente em pé, considerandose o maior valor de cada vogal. Os resultados foram analisados estatisticamente ao nível de significância de $5 \%$. Resultados: faixa de idade representativa; TMF e média menos representativos, abaixo da normalidade e com forte correlação positiva e significativa entre si; correlação moderada, positiva e significativa entre os TMF entre si e sua média. Conclusão: na presença de nódulos vocais em um grupo de mulheres adultas, os TMF encontraram-se reduzidos e positivamente correlacionados, o TMF da vogal /a/ apresentou menor valor quando comparado às demais vogais.

Palavras-Chave: Voz; Fonação; Pregas Vocais; Distúrbios da Voz.

\footnotetext{
Referenciar este material como:

1 Kurtz LO; Cielo CA. Maximum phonation time of vowels in adult women with vocal nodules (original title: Tempos máximos de fonação de vogais em mulheres adultas $\sum 3$ com nódulos vocais). Pró-Fono Revista de Atualização Científica. 2010 out-dez;22(4):451-4
} 


\section{Introduction}

Voice is characterized, under a physiological point of view, as a sound which can be heard by human ear, being produced through phonation, which happens through vocal folds vibration during exhalation, promoting the move of the tunica mucosa, and forming a wave from bottom up 1-3.

Assessment of maximum phonation times (MFT) is a test applied to verify the glottic efficiency objectively, being a common practice in dysphonic patients3-6.

When integrity of vocal folds mucosa is impaired, as in dysphonias by vocal nodules, the muco-wave movement of vocal folds does not occur in harmony because in this kind of pathology there is an increase of mass in the free margin due to the edema. Such increase damages the glottal closure, which may interfere in the values of MFT 3-5,7-11.

The present study aimed at verifying and correlating the values of MPT of vowels in young and middle-aged women with vocal nodules.

\section{Method}

The study derives from database records of patients from a speech therapy school-clinic and it has been approved by the Research Ethics Committee (23081.008439/2007-16 e 0087.0.243.00007). The work is characterized by a transversal, exploratory, non-experimental, retrospective, and quantitative analysis. All the patients from the school-clinic previously signed the Free Consent Term.

Subjects of research were selected according to inclusion and exclusion criteria. The inclusion criteria were: female subjects; young-adult age range(between 20-40 years old) and middle-aged (between 41-60 years old); otorhinolaryngologic diagnosis of vocal nodules, independent of glottal gap.

The exclusion criteria were: smoking or drinking habits; hearing impairment confirmed by audiometric exams; oral breathing or other myofunctional disorders that could interfere in carrying out or sustaining the fones of voice assessment ; another laryngeal pathology associated with vocal nodules; history of neurological, psychiatric, endocrine or gastric disorders; flu or allergy history; previous speech therapy and/or otorhinolaryingology treatments 1 .

After applying the criteria mentioned above, 38 women were selected, aged between $20-53$ years old, with vocal nodules. Initially, subjects were divided into two groups: 29 young adults, aged between $20-40$ years old and 9 middle-aged adults, aged between $41-53$ years old.

Besides anamnesis data and otorhinolaryngologic diagnosis, the following measurements of subjects' records were used: MPT $(\mathrm{a}, \mathrm{i}, \mathrm{u})$ and the mean of MPT of vowels. Collecting these MPT occurs in a standardized way in the school-clinic. Subjects remain standing, with arms along the body, chin parallel to the ground, and they are asked to breathe in deeply and emit a certain fone (vowels / a, i, u/) in normal tone and intensity until breathing out is completed. Three sustained emissions of each phoneme are carried out and timed in seconds. Then, the highest of the three is chosen as the MPT of that fone1,6,12.

MPT values of vowels in the present study were the normality gap between 14,04 and 26,96s, suggested for adult women3.

Data obtained from the database records were first tabulated and analysed through descriptive statistics and the U test of Mann-Whitney in order to prove whether the two independent samples (Young adults $\mathrm{x}$ middle-aged adults ) were selected or not from the same population. This was so to check the possibility of being analysed as only one group.

Later, the Variables Normality tests (Lilliefords) were used to test data normality, and the Spearman Correlation to verify the correlation (positive or negative) between the variables, considering the following values: strong correlation - over 0.7 ; moderate correlation - between 0.3 and 0.7 ; weak correlation - between 0 and 0.29 .

\section{Results}

After applying the U testo f Mann-Whitney, no significant differences were found for MPT and vital capacity (VC) of Young female adults and middleaged female adults separately. This way, with the variable neutralized, both groups were united and data were analysed together (Table 1). 
TABLE 1. Difference of MPT variables of vow els /a, i, u/ and mean of MPT of vowels /a, i, u/ between groups of young female adults and middle-aged female adu lts with vocal nodules in the U Test of Mann-Whitney

\begin{tabular}{|c|c|c|c|c|c|}
\hline \multirow[t]{2}{*}{ Variables } & Mean & Adding up & $U$ & \multirow[t]{2}{*}{$Z$} & \multirow[t]{2}{*}{ p-value } \\
\hline & Ranks & Rank & Test & & \\
\hline Young adults $x$ Middle-aged adults MFT /a/(s) & 610,5 & 130,5 & 94,5 & 0,9130 & 0,3612 \\
\hline Young adults $x$ Middle-aged adults MFT /i/ (s) & 619,5 & 121,5 & 85,5 & 1,2353 & 0,2167 \\
\hline Young adults $x$ Middle-aged adults MFT /u/ (s) & 601,0 & 140,0 & 104,0 & 0,5729 & 0,5667 \\
\hline Young adults $x$ Middle-ag ed adults VOWELS MEAN (s) & 612,5 & 128,5 & 92,5 & 0,9847 & 0,3248 \\
\hline
\end{tabular}

* variables did not show significant difference for young adults and midd le-aged adults; MFT - maximum phonation time.

TABLE 2. Results of coefficient of variation and significance of variables age, MPT of vowels /a, i, u/ and mean of MPT of vo wels /a, i, u/ in adult women with vocal nodules.

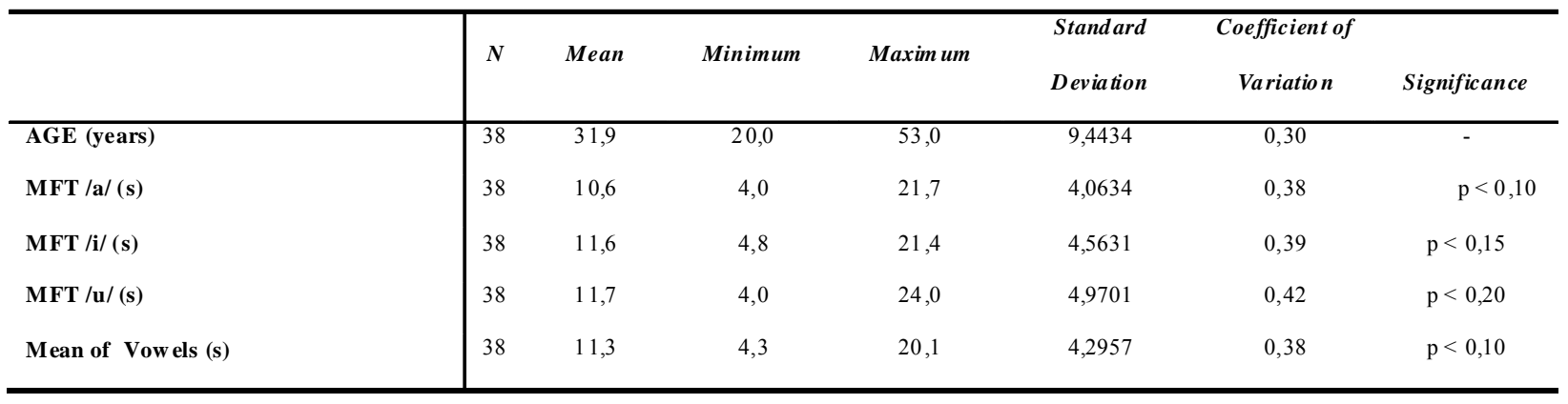

*Coefficient of variation represen tative of mean: valu es between $0-0,30 . ;$ variables do not follow a normal distribution, that is, $\mathrm{p} ;<\alpha(\alpha=5 \%)$ - Lilliefords Test; MF T - maximum phonation time.

TABLE 3. Results of Spearman correlation test between the variables of MPT of vow els /a, i, u/ and mean of MPT of vowels /a, i,

$\mathrm{u} /$ in adult women with vocal nodules

\begin{tabular}{|c|c|c|c|}
\hline Correlations & $\rho$ & $t(N-2)$ & p-value \\
\hline $\mathrm{MFT} / \mathrm{a} / \& \mathrm{MFT} / \mathrm{i} /$ & $0.836591(+)$ & 9.16263 & $0.000000^{*}$ \\
\hline $\mathrm{MFT} / \mathrm{a} / \& \mathrm{MFT} / \mathrm{u} /$ & $0.857292(+)$ & 9.99118 & $0.000000^{*}$ \\
\hline MFT/a/ \& MÉAN OF VOWELS & $0.916491(+)$ & 13.74550 & $0.000000^{*}$ \\
\hline $\mathrm{MFT} / \mathrm{i} / \& \mathrm{MFT} / \mathrm{u} /$ & $0.930780(+)$ & 15.27626 & $0.000000^{*}$ \\
\hline MFT/i/ \& MÉAN OF VOWELS & $0.967167(+)$ & 22.83359 & $0.000000^{*}$ \\
\hline MFT/u/ \& MÉAN OF VOWELS & $0.972493(+)$ & 25.04993 & $0.000000 *$ \\
\hline
\end{tabular}

*variables correlated; $\rho=$ coefficient of correlation of Spearman; $(+)$ positive, strong and sign ificant correlation for $\mathrm{p}$-value; MFT - maximum phonation time; $\mathrm{VC}$ - vital capacity. 


\section{Discussion}

The descriptive analysis showed that age was homogeneous and representative of the sample studied (Table 1). Only the coefficient of variation of MPT of vowels and the mean were a little higher than expected, suggesting intra-group variations (Table 2 ). However, all the MPT and mean values showed a strong positive correlation in the group (Table 3). Intra-group variations could be explained by the variables that may influence MPT, such as age, VC, pneumophonoarticulatory coordination, vocal practice, characteristic of lesion, glottal closure, among others1-6,9. Although these variations were low, it is possible to explain the strong positive correlation between MPT in the group studied, which suggests homogeneity probably due to the uniform variables of the group such as gender, age, and the presence of the same laryngeal pathology.

The mean values of MPT were found decreased when comparing with normality standards established for the study3. Such a finding is in accordance with some authors who state that the presence of laryngeal pathology, located on the margin of vocal folds, as it happens with vocal nodules, results in the decrease of glottal resistance, and a consequent increase of air flow due to a glottal gap, which may appear during phonation. Hence, MPT can be reduced 1-5,9,11.

The previous idea is reinforced by researchers who state that the presence of lesions like the vocal nodules bring alteration in the firmness of glottis, which makes it necessary to redirect the air pressure to start and keep phonation1,2,9-11. Therefore, it is believed that the decreased values of MPT are not only attributed to the presence of lesion, but also to the lack of pneumophonic coordination1,4,6,11. In addition, other unclear factors such as individual compensations 6,10 , increased intravascular pressure of vocal folds during vibration, which can harm the capillaries3,13,14, the characteristics of lesion like the epithelial hyperplasia, thickness of basal membrane, edema and fibrosis with increased fibronectin in the basal membrane, in the lamina propria and around the capillaries $7,11,14$, as well as the gap standard and the mucosa vibration caused by nodules $10,11,14$ also contribute to decreased values of MPT.
It has been found that the mean of MPT of /a/ $(10,6 s)$ was lower compared with MPT of $/ \mathrm{i} /$ and $/ \mathrm{u} /$, which may be justified by the configuration of the vocal tract, because such a vowel is the one which most shows dysphonia due to its articulatory nature, which makes it evident the minimum alterations in the myoelastic balance of larynx. Thus, it is classified as a central and open vowel, and it is the most valued in any voice test 1,6 . It is assumed that, due to the opening and decrease of length of the vocal tract constrictions in relation to the other vowels 15,16 , there might have been a greater air escape in a shorter time.

Still, by analyzing different vowels, it has been noted the influence of articulation variability, the difficulty in assessing the movement of the walls in the vocal tract, the role of the pyriform sinus as well as the length of the vocal tract in producing the different 17. In another study, it was found that there are significant differences between vowels sustained with normal voice and with pathologic voica8. It has also been noted that among the Brazilian Portuguese vowels, only vowel /?/ suffers less influence of vocal tract changes 18. The individual compensations are also highlighted in the emission of MPT6. These could be the variables intervening in the MPT differences found in the present study, showing the necessity of further studies to determine the characteristics of vowels.

\section{Conclusion}

The values of MPT are decreased in female subjects with vocal nodules, possibly due to the presence of pathology, which hás as its cause the incomplete glottal closure.

MPT of vowels and the mean values showed the result of coefficient of variation a little higher than expected, suggesting intra-group variation, justified by factors that may influence MPT other than gender and pathology, such as age, $\mathrm{VC}$, pneumophonoarticulatory coordination, among others.

However, MPT of vowels and the mean showed strong positive correlation, suggesting homogeneity in the group studied.

MPT of vowel /a/ showed lower value when compared to the other vowels, possibly due to the configuration that the vocal tract assumes when producing such a vowel. 


\section{References}

1. Behlau M. Voz: O Livro do Especialista. Vol. 1. Rio de Janeiro: Revinter, 2001. p. 348.

2. Barros APB, Carrara-de-Angelis E. Avaliação Percepção Auditiva da Voz. In: Dedivits RA; Barros APB. Métodos de Avaliação e Diagnóstico de Laringe e Voz. São Paulo: Lovise; 2002.

3. Beber BC, Cielo CA, Siqueira MA. Lesões de Borda de pregas vocais e Tempos Máximos de Fonação. Rev. CEFAC. 2009;11(1):134-41.

4. Mendes A, Castro E. Análise acústica da avaliação vocal: Tarefas fonatórias e medidas acústicas. Rev Port Otorrinolaringol Cir Cerv Fac. 2005;43(2):127-36.

5. Speyer R, Bogaardt HCA, Passos VL, Roodenburg NPHD, Zumach A, Heijnen MAM, Baijens LWJ, Fleskens SJHM, Brunings JW. Maximum Phonation Time: Variability and Reliability. Journal of Voice. 2010; 24(3):281-84.

6. Rossi DC, Munhoz DF, Nogueira CR, Oliveira CM, Britto ATBO. Relação do pico de fluxo expiratório com o tempo de fonação em pacientes asmáticos. Rev. CEFAC. 2006;8(4):509-17.

7. Martins RHG, Defaveri J, Domingues MAC, Silva RA, Fabro A. Vocal Fold Nodules: Morphological and Immunohistochemical Investigations. Journal of Voice. 2010;24(5):531-39.

8. Zhang Y, Jiang JJ. Acoustic analyses of sustained and running voices from patients with laryngeal pathologies. Journal of Voice. 2008;22(1):1-9.

9. Ruiz DMCF, Pontes P, Behlau M, Richieri-Costa A. Laryngeal Microweb and Vocal Nodules - Clinical Study in a Brazilian Population. Folia Phoniatr Logop. 2006;58(6):392-9.
10. Dejonckere PH, Kob M. Pathogenesis of Vocal Fold Nodules: New Insights from a Modelling Approach. Folia Phoniatr Logop. 2009; 61(3): 171-9.

11. Johns MM. Update on the etiology, diagnosis, and treatment of vocal fold nodules, polyps, and cysts. Curr Opin Otolaryngol Head Neck Surg. 2003; 11(6):456-61.

12. Gelfer MP, Pazera JF. Maximum duration of sustained $/ \mathrm{s} /$ and $/ \mathrm{z} /$ and the $\mathrm{s} / \mathrm{z}$ ratio with controlled intensity. Journal of Voice. 2006;20(3):369-79.

13. Czerwonka L, Jiang JJ, Tao C. Vocal nodules and edema may be due to vibration-induced rises in capillary pressure. Laryngoscope. 2008;118(4):748-52.

14. Karkos PD, McCormick M. The etiology of vocal fold nodules in adults. Curr Opin Otolaryngol Head Neck Surg. $2009 ; 17(6): 420-23$.

15. Lima MFB, Camargo ZA, Ferreira LP, Madureira S. Qualidade vocal e formantes das vogais de falantes adultos da cidade de João Pessoa. Rev. CEFAC. 2007;9(1):99-109.

16. Ahmad M, Dargaud J, Morin A, Cotton F. Dynamic MRI of Larynx and Vocal Fold Vibrations in Normal Phonation. Journal of Voice. 2009;23(2):235-39.

17. Clément $P$, Hans S, Hartl DM, Maeda S, Vaissière J, Brasnu D. Vocal Tract Area Function for Vowels Using Three-Dimensional Magnetic Resonance Imaging - A Preliminary Study. Journal of Voice. 2007;21(5):522-30.

18. Gonçalves MIR, Pontes PAL, Vieira VP, Pontes AAL, Curcio D, Biase NG. Função de transferência das vogais orais do Português brasileiro: análise acústica comparativa. Braz. j. otorhinolaryngol. 2009;75(5):680-84. 